\title{
Issues in LAW
}

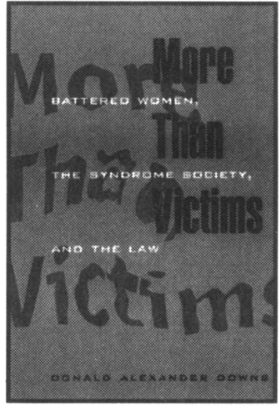

More Than Victims

Battered Women, the Syndrome Society, and the Law

\section{Donald Alexander Downs}

"This is the first serious effort to locate the debate about abuse, excuses, and the culpability of battered women who kill in a broader ideological framework." -George P. Fletcher, Columbia University

Cloth $\$ 27.50320$ pages

Morality and Society series

\section{The Pursuit of Absolute Integrity}

How Corruption Control Makes

Government Ineffective

Frank Anechiarico and James B. Jacobs

"In this splendid volume, Anechiarico and Jacobs show that current efforts to eradicate corruption amount to a cure that is far worse than the disease." -Benjamin Ginsberg, Johns Hopkins University

Cloth \$24.95 296 pages

Studies in Crime and Justice

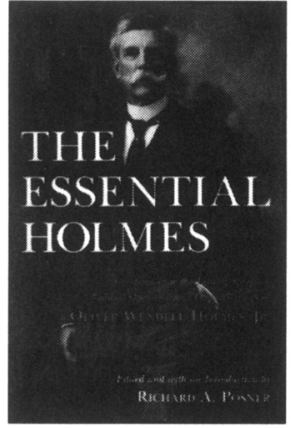

\section{The Essential Holmes}

Selections from the Letters,

Speeches, Judicial Opinions, and Other Writings of Oliver Wendell

Holmes, Jr.

\section{Edited and with an Introduction by} Richard A. Posner

"Brilliantly edited, lucidly organized, and equipped with a compelling introduction by Judge Posner, [this book] is one of the finest single-volume samplers of any author's work I have seen." - Terry Teachout, National Review

*Paper \$15.95 374 pages

\section{Bloodtaking and Peacemaking}

Feud, Law, and Society in Saga Iceland

\section{William lan Miller}

"An impressive achievement. . . A pleasure to read due to the inclusion of narrative case material from the sagas themselves."

-Dan Bauer, Journal of Interdisciplinary History

*Paper \$17.95 422 pages

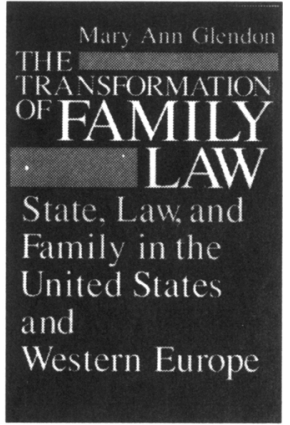

The Transformation of Family Law

State, Law, and Family in the United States and Western Europe

\section{Mary Ann Glendon}

"[Glendon] has painted a portrait of the family in which we recognize not only ourselves but also unremembered ideological forefathers. ... It sends our thoughts out into unexpected adventures."

- Inga Markovits, Michigan Law

Review

•Paper \$15.95 336 pages

\section{Imperfect Alternatives}

Choosing Institutions in Law, Economics, and Public Policy

\section{Neil K. Komesar}

"Likely to be one of the most significant works of this decade." -Edward L. Rubin, Wisconsin Law Review

Paper \$17.95 299 pages 


\section{Ethics}

an international journal of social, political, and legal philosophy

How you can stay apprised of today's most influential scholarship in the field of ethics?

Ethics has not only published classic works by such renowned authors as F.H. Bradley, John Dewey, William James, G.E. Moore, A.C. Pigou, Bertrand Russell, and Henry Sidgwick, the journal maintains a dedication to quality by publishing the scholarship of some of today's most innovative and original thinkers such as Brian Barry, Jon Elster, T.H. Irwin, Joseph Raz, G.A. Cohen, and Allan Gibbard. Recent contributors include Blackburn, Annette C. Baier, John Martin Fischer, and Mark Ravizza.

Recent articles include

Distributive Justice: What the People Think, David Miller

Coping with Moral Conflict and Ambiguity, David Wong

Conflict and Inquiry, Issac Levi

Constrained Indeterminacy and Political Discourse, Thomas Seung

A Cosmopolitan Perspective on the Future of Sovereignty, Thomas Pogge

Superseding Historical Injustice, Jeremy Waldron

One-year subscription rates: Individuals $\$ 28.00$; Institutions $\$ 56.00$;

APA Individual Members \$22.50; Students (with copy of ID) 20.00.

Outside USA add $\$ 5.00$. Visa and MasterCard accepted. To subscribe, send check or complete charge card information to The University of Chicagu Press, Journals Division, Dept. SW3SA, P.O. Box 37005, Chicago, IL 60637.

STATEMENT OF OWNERSHIP, MANAGEMENT AND CIRCULATION (Required by 39 U.S.C. 3685 )

1. Publication title: Law and Social Inquiry: Journal of the American Bar Foundation

2. Publication number: 0036-1170

3. Filing date: September 27,1996

4. Issue frequency: Quarterly

5. No. of issues published annually: 4

6. Annual subscription price: $\$ 59.00$

7. Complete mailing address of known office of publication: 5720 South Woodlawn Ave., Chicago, Cook, IL 60637-1603

8. Complete mailing address of the headquarters or general business offices of the publishers: 5720 South Woodlawn Ave., Chicago, Cook, IL 60637-1603

9. Full names and complete mailing addresses of publisher, editor, and managing editor:

Publisher: The University of Chicago Press, 5720 South

Woodlawn Ave., Chicago, IL 60637-1603

Editor: Carol A. Heimer and Elizabeth Mertz. American Bar

Foundation, 750 North Lake Shore Drive, Chicago, IL 606114403

Managing Editor: John Atkinson, American Bar Foundation, 750 North Lake Shore Drive, Chicago, IL 60611-4403

10. Owner: American Bar Foundation, 750 North Lake Shore Drive, Chicago, IL 60611

11. Known bondholders, mortgagees, and other security holders owning or holding 1 percent or more of total amount of bonds. mortgages or other securities: None

12. The purpose, function, and nonprofit status of this organization and the exempt status for Federal income tax purposes have not changed during preceding 12 months

13. Publication name: Law and Social Inquiry: Journal of the American Bar Association

14. Issue date for circulation data below: Spring 1996, Volume 21, Number 2

\begin{tabular}{|c|c|c|c|}
\hline \multicolumn{2}{|r|}{ 15. Extent and nature of circulation: } & $\begin{array}{l}\text { Average } \\
\text { Number } \\
\text { Copies } \\
\text { Each Issue } \\
\text { During } \\
\text { Preceding } \\
12 \text { Months }\end{array}$ & $\begin{array}{l}\text { Actual } \\
\text { Number } \\
\text { Copies of } \\
\text { Single Issue } \\
\text { Published } \\
\text { Nearest to } \\
\text { Filing Date }\end{array}$ \\
\hline a. & Total number copies printed & 2,429 & 2,430 \\
\hline b. & $\begin{array}{l}\text { Paid circulation: } \\
\text { 1. Sales through dealers } \\
\text { and carriers, street } \\
\text { vendors and counter } \\
\text { sales } \\
\text { 2. Mail subscription }\end{array}$ & $\begin{array}{r}0 \\
1,758\end{array}$ & $\begin{array}{r}\prime \\
1,720\end{array}$ \\
\hline c. & $\begin{array}{l}\text { Total paid and/or requested } \\
\text { circulation }\end{array}$ & 1,758 & 1,721 \\
\hline d. & $\begin{array}{l}\text { Free distribution by mail } \\
\text { (samples, complimentary, } \\
\text { and other free copies) }\end{array}$ & 41 & 41 \\
\hline e. & Free distribution outside the mail & 0 & 0 \\
\hline f. & $\begin{array}{l}\text { Total free distribution } \\
\text { (sum of } d \& \text { e) }\end{array}$ & 41 & 41 \\
\hline g. & $\begin{array}{l}\text { Total distribution } \\
\text { (sum of c \& f) }\end{array}$ & 1,799 & 1,762 \\
\hline h. & $\begin{array}{l}\text { Copies not distributed: } \\
\text { 1. Office use, left over, } \\
\text { spoiled } \\
\text { 2. Returns from news } \\
\text { agents }\end{array}$ & $\begin{array}{r}630 \\
0\end{array}$ & $\begin{array}{r}668 \\
0\end{array}$ \\
\hline i. & Total (sum of $\mathrm{g}, \mathrm{hl}$ and 2 ) & 2,429 & 2,430 \\
\hline & $\begin{array}{l}\text { tt paid and/or Requested } \\
\text { ation }\end{array}$ & $\%$ & $98 \%$ \\
\hline
\end{tabular}

16. This Statement of Ownership will be printed in the Fall 1996 issue of this publication.

17. I certify that all information furnished on this form is true and complete. I understand that anyone who furnishes false or misleading information on this form or who omits material or information requested on the form may be subject to criminal sanctions (including fines and imprisonment) and/or civil sanctions (including multiple damages and civil penalties). 


\section{Law and Social Inquiry}

\section{Socio-legal research wouldn't be the same without it.}

This is a journal that has played a major role in shaping current theory and methods, in generating discussion and commentary, in advancing the field — that's why you're reading this issue. But if you're not a subscriber, you could be missing important developments. If you don't want to miss a single issue-and you' $d$ like to take advantage of a $15 \%$ introductory discountorder today.

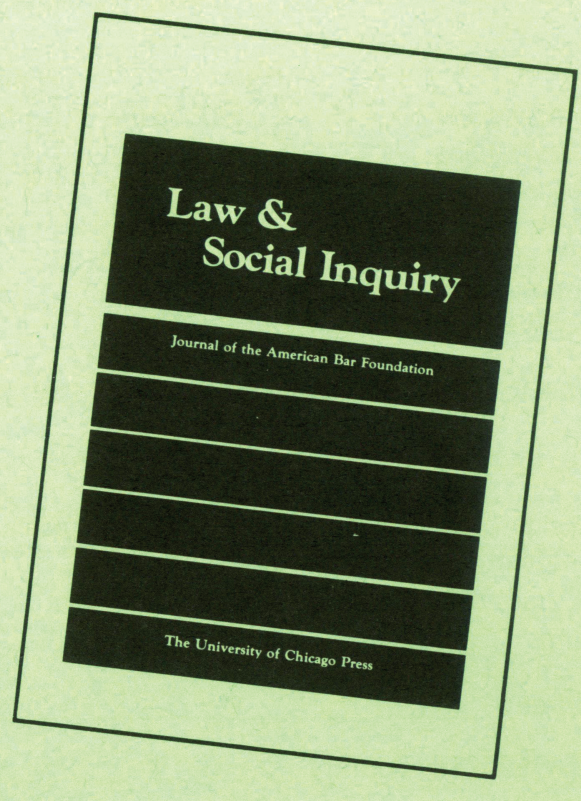

\section{Save $15 \%$ using the order form on reverse.}

\section{Law and Social Inquiry}

\section{Socio-legal research wouldn't be the same without it.}

This is a journal that has played a major role in shaping current theory and methods, in generating discussion and commentary, in advancing the field - that's why you're reading this issue. But if you're not a subscriber, you could be missing important developments. If you don't want to miss a single issue-and you'd like to take advantage of a $15 \%$ introductory discountorder today.

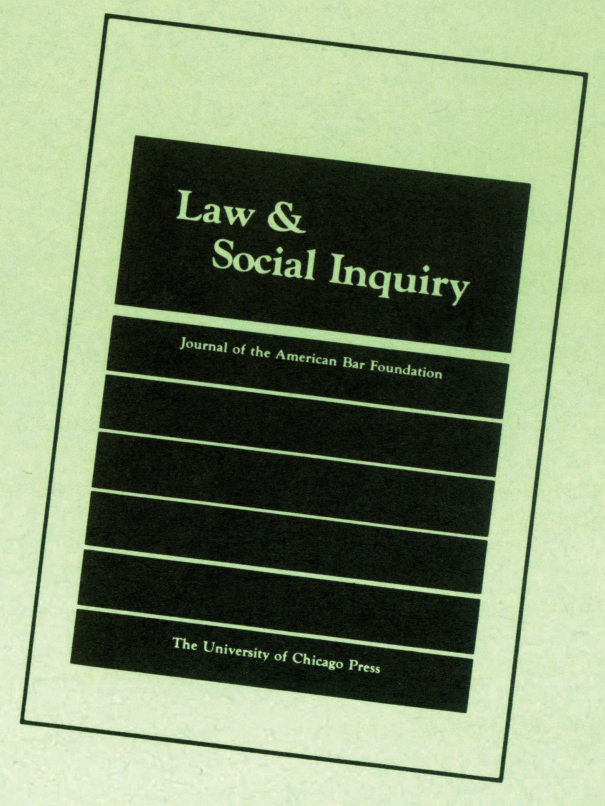




\section{Enter a new subscription and save $25 \%$ !}

\begin{tabular}{lll}
$\square$ Individuals & New & Renewal \\
$\square$ Institutions & $\square \$ 27.00$ (F) & $\square \$ 36.00$ \\
$\square$ Academics* & $\square$ 44.25 (F) & $\square 9.00$ \\
\hline 21.75 (F) & $\square 29.00$
\end{tabular}

*For college/university faculty and students.

Outside USA: please add $\$ 6$ for postage.

Canadian residents: please add $7 \%$ GST.

Back issues: remaining issues (vol. 14-19) at $50 \%$ off:

$\square \$ 115.00$ Individuals $\square \$ 181.10$ Institutions

Outside USA: please add $75 \varnothing$ per issue for postage.

Canadian residents: please add $7 \%$ GST.

Payment Options
Orders must include payment in U.S. dollars.
Fax credit card orders to:
(312) $753-0811$ (before October 12, 1996)
(773) $753-0811$ (effective October 12, 1996)
$\square$ Charge $\square$ MasterCard $\square$ Visa
Expiration date
Account no.
Signature
Phone number
$\square$ Check enclosed (in U.S. dollars drawn from a U.S.
bank, payable to the journal)

Name

Address

City/State/Zip/Country

Visit our website at http://www.journals.uchicago.edu/

For special savings on two and three year rates, please direct inquiries to address listed below.

Please send your order to The University of Chicago Press, Journals Division, P.O. Box 37005, Chicago, IL 60637 USA.

\section{Law \& Social Inquiry}

\section{Enter a new subscription and save $25 \%$ !}

$\begin{array}{lll}\square \text { Individuals } & \text { New } & \text { Renewal } \\ \square \text { Institutions } & \square \$ 27.00 \text { (F) } & \square \$ 36.00 \\ \square \text { Academics* } & \square 44.25 \text { (F) } & \square 59.00 \\ 21.75 \text { (F) } & \square 29.00\end{array}$

*For college/university faculty and students.

Outside USA: please add $\$ 6$ for postage.

Canadian residents: please add $7 \%$ GST.

Back issues: remaining issues (vol. 14-19) at $50 \%$ off:
$\$ 115.00$ Individuals
$\$ 181.10$ Institutions

Outside USA: please add $75 \varnothing$ per issue for postage. Canadian residents: please add $7 \%$ GST.

Payment Options
Orders must include payment in U.S. dollars.
Fax credit card orders to:
(312) 753-0811 (before October 12, 1996)
(773) 753-0811 (effective October 12, 1996)
$\square$ Charge $\square$ MasterCard $\square$ Visa
Expiration date
Account no.
Signature
Phone number
$\square$ Check enclosed (in U.S. dollars drawn from a U.S.
bank, payable to the journal)

Name

Address

City/State/Zip/Country 


\section{American Bar Foundation}

\section{BOARD OF DIRECTORS}

President, Robert MacCrate, of the New York Bar - Vice-President, Kenneth J. Burns, Jr., of the Illinois Bar - Secretary, Hon. Jerome Farris, United States Court of Appeals, Ninth Circuit • Treasurer, Jacqueline Allee, of the Florida Bar

Brooksley E. Born, of the District of Columbia Bar - Rachelle DesVaux, of the Florida Bar - Robert O. Hetlage, of the Missouri Bar - James W. Hewitt, of the Nebraska Bar • Herma Hill Kay, University of California at Berkeley School of Law - Carrie Menkel-Meadow, Georgetown University Law Center • M. Peter Moser, of the Maryland Bar - David E. VanZandt, of the Illinois Bar

ex officio:

N. Lee Cooper, President, American Bar Association • Jerome J. Shestack, President-Elect, American Bar Association - A. P. Carlton, Chair, House of Delegates, American Bar Association - John A. Krsul, Jr., Treasurer, American Bar Association - Arthur W. Leibold, President, American Bar Endowment - Joseph A. Woods, Jr., Chair, The Fellows of the American Bar Foundation - Leonard H. Gilbert, Vice-Chair, The Fellows of the American Bar Foundation - John L. Carey, Secretary, The Fellows of the American Bar Foundation

\section{OFFICERS}

Bryant G. Garth, Director Joanne Martin, Assistant Director
Anne Tatalovich, Assistant Director

Hayden C. Flor, Jr., Financial Officer

\section{RESEARCH FELLOWS}

Lori B. Andrews, J.D. Yale University

Jonathan D. Casper, Ph.D. Yale University

John L. Comaroff, Ph.D. University of London

Stephen Daniels, Ph.D. University of Wisconsin

Shari S. Diamond, Ph.D. Northwestern University;

J.D. University of Chicago

Bryant G. Garth, J.D. Stanford University; Ph.D.

European University Institute

Janet A. Gilboy, Ph.D. Northwestern University

Terence C. Halliday, Ph.D. University of Chicago

James J. Heckman, Ph.D. Princeton

Carol A. Heimer, Ph.D. University of Chicago

John P. Heinz, LL.B. Yale University
Karyl A. Kinsey, Ph.D. University of Chicago

E. Allan Lind, Ph.D. University of North Carolina at Chapel Hill

Elizabeth Mertz, J.D. Northwestern University; Ph.D. Duke University

Robert L. Nelson, J.D., Ph.D. Northwestern University

Robert J. Sampson, Ph.D. State University of New York at Albany

Susan P. Shapiro, Ph.D. Yale University

Christopher L. Tomlins, Ph.D. Johns Hopkins

Victoria Saker Woeste, Ph.D. University of California, Berkeley

\section{VISITING RESEARCH FELLOWS}

Wendy Espeland, Assistant Professor of Sociology, Northwestern University

Arthur L. Stinchcombe, Part-time Professor of Sociology, Northwestern University

\section{LIAISON RESEARCH SERVICES PROGRAM}

Joanne Martin, M. M. Northwestern University, J.D. Loyola University

Barbara A. Curran, LL.B. University of Connecticut, LL.M. Yale University 


\section{Law \& Social Inquiry \\ Volume 21, Number 4, Fall 1996}

\section{ARTICLES}

Distributing Responsibility for Wrongdoing Inside Corporate Hierarchies: Public Judgments in Three Societies JOSEPH SANDERS AND V. LEE HAMILTON ET AL

Liberty, Protection, and Women's Work: Investigating the Boundaries between

Public and Private JULIE NOVKOV

\section{REVIEW SECTION SYMPOSIUM}

\section{Law and Institutional Analysis}

Legal Rational Myths: The New Institutionalism and the Law and Society

Tradition MARK C. SUCHMAN AND LAUREN B. EDELMAN

Rethinking Social Control JOHN R. SUTTON

Fields of Practice: Connections between Law and Organizations WALTER W. POWELL

\section{REVIEW SECTION SYMPOSIUM}

\section{Law Schools and Legal Scholarship}

The Lost Law Professor DANIEL R. ERNST

Talkin' Dirty: Twining's Tower and Kalman's Strange Career JOHN HENRY SCHLEGEL

Commentary on Schlegel

Garbage-Mouth

LAURA KALMAN

\section{Rethinking Law Schools} WILLIAM TWINING

\section{REVIEW ESSAYS}

The Company We Keep: Kronman's The Lost Lauyer and the Development of Moral Imagination in the Practice of Law

TANINA ROSTAIN

Property Rules or the Rule of Property? Carol Rose on the History, Theory, and Rhetoric of Ownership JEREMY ADELMAN

"Supreme Fictions": L. H. LaRue's Constitutional Law as Fiction LIEF CARTER

\section{BOOK NOTES}

\section{INDEX TO VOLUME 21}

